\title{
Konstrukcje stalowe pełnomorskie (offshore) - rodzaje, remonty
}

\section{Offshore steel structures: types and repairs}

\section{Streszczenie}

W ostatnich latach obserwuje się ciągły wzrost zapotrzebowania na surowce energetyczne, a zwłaszcza na ropę naftową. Rozwijająca się cywilizacja i przemysł potrzebują coraz większej ilości tego surowca. Aby temu sprostać, człowiek poszukuje nowych miejsc jego wydobywania. Obecnie w związku z wyczerpywaniem się złóż ropy naftowej na lądzie, ogromnym zainteresowaniem cieszy się wydobywanie minerałów spod dna morskiego. Realizuje się je, wykorzystując konstrukcje pełnomorskie (offshore), które niejednokrotnie pracuja w ekstremalnych warunkach (rejony arktyczne), aby zaspokoić zapotrzebowanie na ropę naftową.
Abstract

The demand for sources of energy, especially for crude oil, keeps increasing in recent times. Development of civilisation and industry means that more and more crude oil will be required in the future. In order to meet this demand people are looking for new resources. Given that land oil accumulations become more and more depleted offshore production, i.e. oil mining from drilling platforms, is given closer attention. This technology employs offshore structures which must be often operated under extreme conditions (arctic regions) so as to meet the escalating necessities.

\section{Konstrukcje offshore}

Terminem offshore określa się instalacje poszukiwawcze, wydobywcze, przetwórcze i transportujące pracujące na pełnym morzu. Konstrukcje te służą do eksploatacji złóż minerałów znajdujących się pod dnem morza. Pojęcie to obejmuje również jednostki niezbędne do obsługi konstrukcji pracujących na pełnym morzu.

Pomysł poszukiwania ropy naftowej na morzu powstał po zakończeniu II wojny światowej. W 1947 r. zainstalowano pierwsza stalowa platformę wiertniczą na głębokości $6 \mathrm{~m}$ na polu Louisiana State Tease w Zatoce Meksykańskiej. Została ona zbudowana z pokładem o powierzchni wynoszącej 11,6 x 21,6 m (251 $\left.\mathrm{m}^{2}\right)$ przez firmę Kerr-Mc Gee Corp. Platformę oparto na 16 stalowych palach o średnicy $610 \mathrm{~mm}$ i długości 42,7 m. Pale wchodziły średnio $31,7 \mathrm{~m}$ w dno morskie zbudowane z piasków. Wieża wiertnicza ustawiona na platformie umożliwiała wiercenie na głębokości $3000 \mathrm{~m}$. Platforma była czynna do 1983 r. [1].

Pierwsze platformy były budowane już w 1933 r., przy czym pierwszą niezależną platformę ustawiono na głębokości wody 4,3 m w 1937 r.; dotyczy to jednak wód śródlądowych, osłoniętych, gdzie falowanie nie było podstawowym obciążeniem platformy [1]. W 1954 r. A.J. „Doc” LaBorde zaprojektował i zbudował własną konstrukcję pełnomorską nazwaną Mr Charlie. Długość jednostki wynosiła w przybliżeniu $67 \mathrm{~m}$, szerokość $26 \mathrm{~m}$, a wysokość $41 \mathrm{~m}$. Załoga tej platformy składała się z 58 osób. Była to pierwsza platforma półzanurzona przeznaczona na płytkie wody (pierwszy odwiert na głębokości $12 \mathrm{~m}$ ), która umożliwiała odpłynięcie $\mathrm{w}$ inne miejsce po dokonaniu odwiertu (rys. 1) [2].

Dr inż. Ryszard Pakos, mgr inż. Ernest Romek - Zachodniopomorski Uniwersytet Technologiczny w Szczecinie.

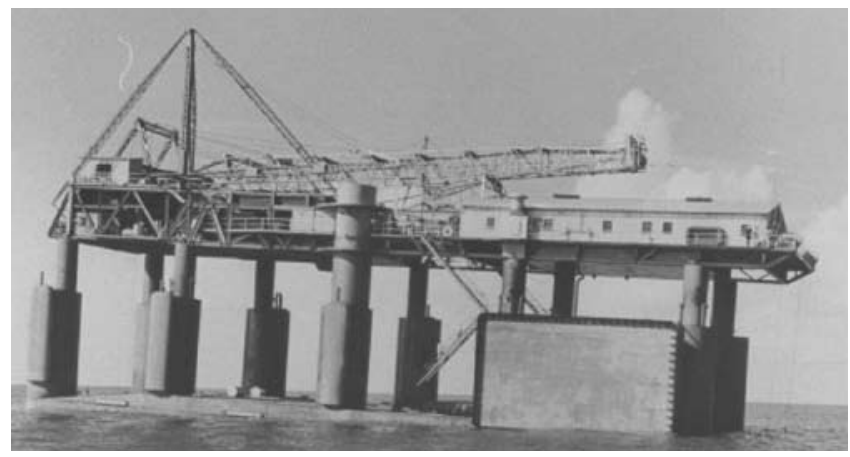

Rys. 1. Pierwsza na świecie platforma półzanurzona Mr Charlie [6] Fig. 1. Mr Charlie Platform: the first ever semi-submersible platform [6]

\section{Rodzaje konstrukcji offshore}

Zasadniczo konstrukcje pełnomorskie można podzielić na trzy grupy: platformy, statki wiertnicze oraz pływające punkty produkcji, przechowywania i załadunku (FPSO).

\section{Platformy}

Są to konstrukcje stalowe lub żelbetonowe wyposażone w urządzenia do poszukiwania, wydobywania, przetwarzania i magazynowania minerałów spod dna morza. Mają wydzieloną część mieszkalną dla załogi, niekiedy ze względów bezpieczeństwa jest to osobna platforma [1, 4]. Platforma jest również wyposażona w instalację umożliwiająca jej prace przez $24 \mathrm{~h}$ na dobę, są to m.in.: generatory prądu oraz stacje produkujące słodką wodę. Ze względu na konstrukcje platformy można podzielić na:

Platformy stalowe wieżowe. Charakteryzują się wieżą w postaci kratownicy przestrzennej posadowionej na palach, na której ustawiony jest pokład, a na nim zlokalizowany jest 


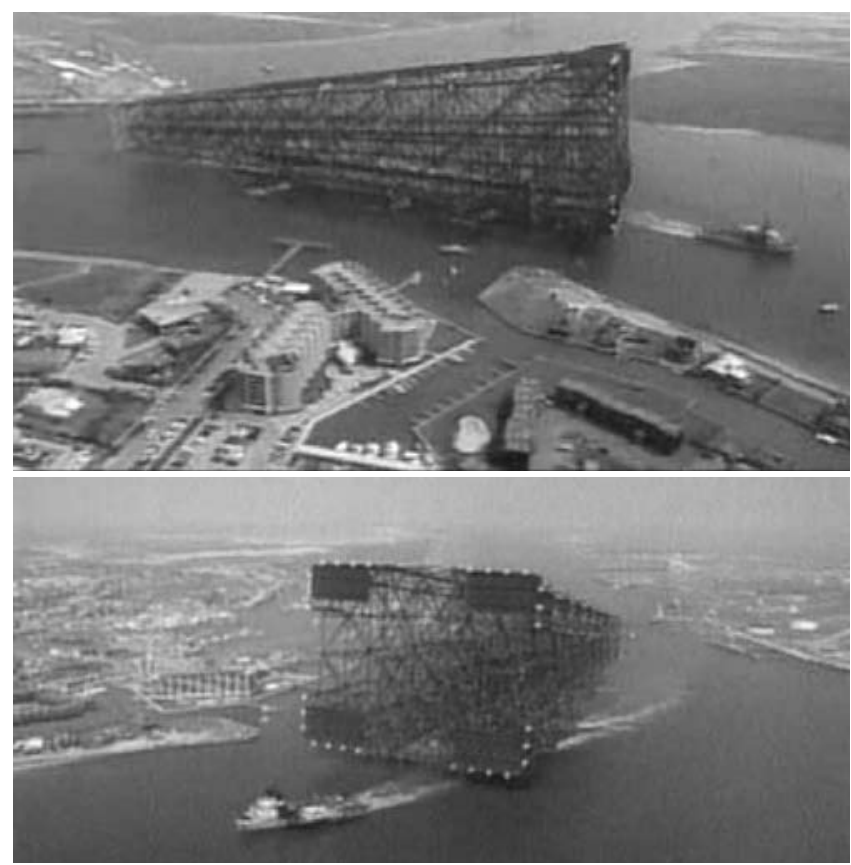

Rys. 2. Transport na barce największej na świecie wieży wykonanej w całości dla platformy Bullwinkle [2]

Fig. 2. The biggest offshore tower in the world on a lighter en route to its ultimate destination - Bullwinkle Platform [2]

zespół urządzeń wiertniczych, wydobywczych i przetwórczych w zależności od przeznaczenia danej platformy [1]. Platformy wieżowe mają wieże wykonane $z$ rur stalowych o różnych średnicach, łączonych ze sobą metodą spawania. Wytworzenie węzłów i połączenie schodzących się w danym węźle rur jest głównym problemem projektowania i wykonawstwa platform stalowych wieżowych. Z tego względu dąży się do tego, aby przyjęte rozwiązania dawały jak najmniejszą liczbę prętów łączonych w jednym węźle [1]. W celu uzyskania większej pewności i wytrzymałości węzłów wykonuje się je w postaci odlewów lub prefabrykatów pozwalających wg wstępnych ocen na uzyskanie 4-krotnego wzrostu wytrzymałości zmęczeniowej. W niektórych badaniach uzyskano wzrost 18-krotny w stosunku do wytrzymałości zmęczeniowej węzłów spawanych [1]. Największą na świecie wieżę zbudowano w Teksasie w 1988 r. i przetransportowano ją (rys. 2) na miejsce posadowienia dla platformy Bullwinkle. Wysokość tej platformy wynosi $529 \mathrm{~m}$, a masa samej wieży 77 tys. ton. Budowa platformy kosztowała 500 milionów dolarów. Platforma ta wydobywa 200 tys. baryłek ropy naftowej i $306 \mathrm{mln} \mathrm{m}^{3}$ gazu dziennie.

Platformy grawitacyjne stałe. Platformy te są przeznaczone do długotrwałej eksploatacji złoża. Są posadowione na dnie morskim, z reguły na betonowej podbudowie, z której ponad powierzchnię wody wystają podparcia o konstrukcji be-

Tablica I. Parametry techniczno-eksploatacyjne platformy Troll A [4]

Table I. Technical and operating parameters of Troll A Platform [4]

\begin{tabular}{|l|c|}
\hline \multicolumn{1}{|c|}{ Operator } & Statoil \\
\hline Rozpoczęcie eksploatacji & $1996 \mathrm{r}$. \\
\hline Przewidywany czas eksploatacji & 70 lat \\
\hline Wysokość całkowita & $472 \mathrm{~m}$ \\
\hline Głębokość w miejscu pracy & $303 \mathrm{~m}$ \\
\hline Wymiary główne platformy & $170 \times 51 \mathrm{~m}$ \\
\hline Masa konstrukcji & $\begin{array}{c}656 \text { tys. } t, \mathrm{w} \text { tym } \\
\end{array}$ \\
\hline
\end{tabular}

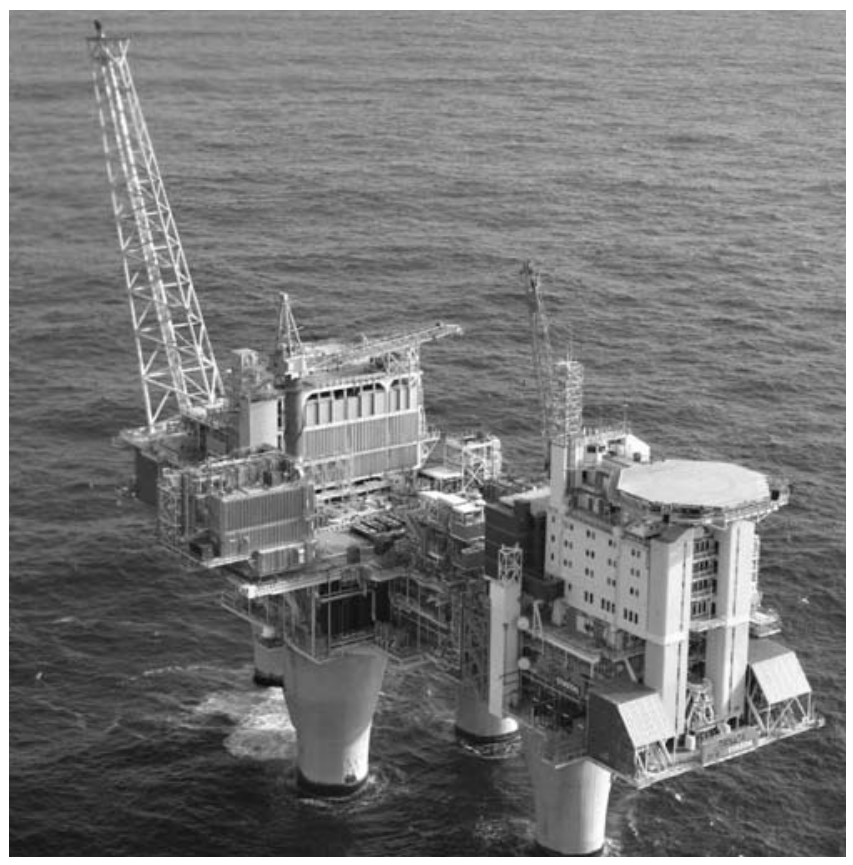

Rys. 3. Platforma Troll A [5]

Fig. 3. Troll A Platform [5]

tonowo-stalowej. Na nich ustawiona jest właściwa platforma. Konstrukcje takie są eksploatowane na akwenach, których głębokość nie przekracza zazwyczaj 300 m [4]. Przykładem takiej platformy jest platforma Troll A, posadowiona na Morzu Północnym do eksploatacji złóż gazu (rys. 3).

Platformy dla rejonów arktycznych. Rozwiązania konstrukcyjne tych platform różnią się znacznie od platform konwencjonalnych i zapewniają przede wszystkim przyjęcie obciążeń wywieranych przez lód arktyczny (rys. 4, 5, 6). Oddziaływanie lodu arktycznego jest zdeterminowane dwoma podstawowymi czynnikami: rodzajem lodu, a więc czy jest to lód dryfujący, czy lód związany z lądem, oraz wiekiem lodu, a więc czy jest to lód jednoroczny, czy też wieloletni [1]. Konstrukcja platformy musi być tak zaprojektowana, aby energia kinetyczna uderzenia pola lodowego została wytłumiona kruszeniem, łamaniem i przemieszczaniem lodu przez podatność podłoża, na którym ustawiono platformę [1]. Niezwykle groźnym czynnikiem dla platform w warunkach arktycznych jest erozja denna spowodowana głównie przesuwającymi się po dnie grzbietami lodowymi.
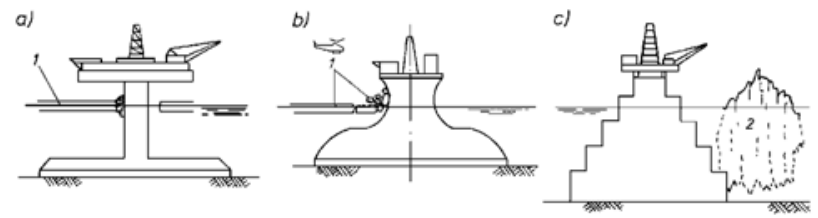

Rys. 4. Rozwiązania platform dla obszarów arktycznych: a - platformy umożliwiające redukcję obciążeń od lodu (minimalna powierzchnia w poziomie pochodu lodów), b - platforma stożkowa (podnoszenie lodu powodujące łamanie w wyniku zginania), c - platforma przenosząca ścinanie (przechwytywanie uderzenia lodu poniżej linii wodnej); 1 - lód, 2 - góra lodowa [1]

Fig. 4. Platform solutions adapted to arctic environments: a - platforms which ensure ice load reduction (the minimum area at the ice drifting level), $b$ - conical platform (ice rising brings about cracking as a consequence of the bending stress), $\mathrm{c}$ - shearing stress transferring platform (intercepts ice impact under the water line); 1 - ice, 2 - iceberg [1] 


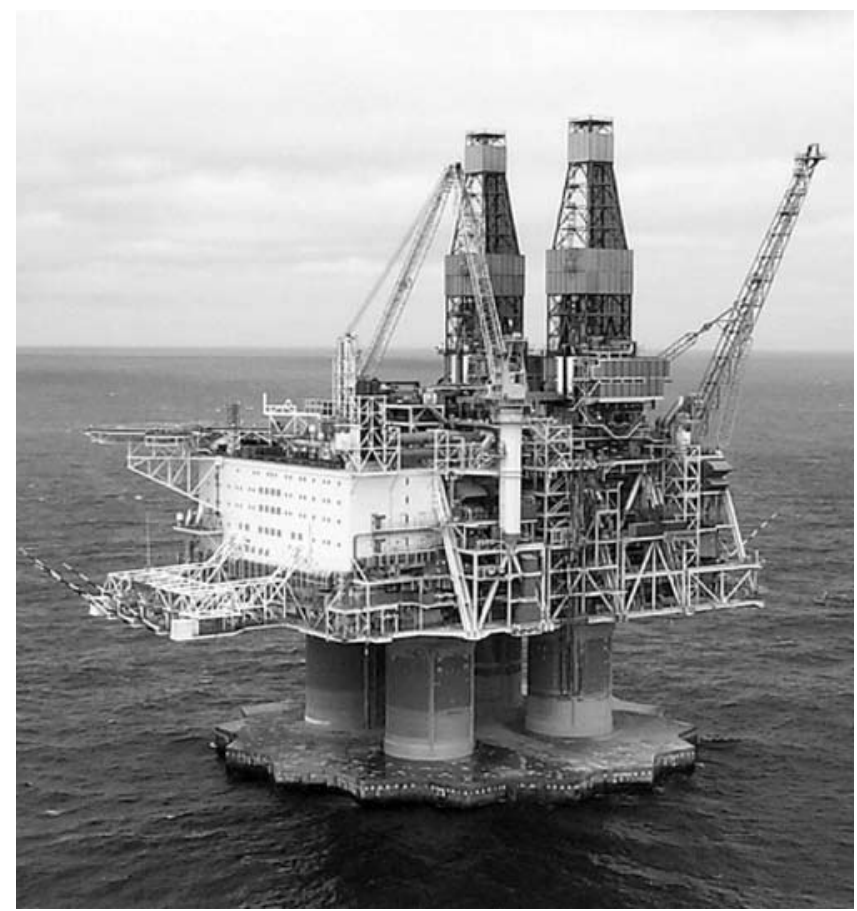

Rys. 5. Platforma Hibernia. Stoi niedaleko od brzegów Nowej Funlandii i jest najcięższą platformą na świecie. Jej całkowita masa wynosi $1,2 \mathrm{mln}$ ton, na co składają się: 37 tys. ton części nadwodnej (topside) umieszczonej na podstawie o masie 600 tys. ton, i stały balast o masie 450 tys. ton, który był dodany, aby zabezpieczyć platformę przed przesuniecciem. Wewnatrz podstawy znajduja się zbiorniki zdolne przechować $1,3 \mathrm{mln}$ baryłek ropy naftowej. Konstrukcja jest tak zaprojektowana, aby nie dopuścić do uszkodzenia platformy przez góry lodowe [15]

Fig. 5. Hibernia Platform at the Newfoundland shores. The heaviest platform in the world weighs $1.2 \mathrm{mln}$ tons, including: 37 thousand tons of topside components which are set on a base structure weighing 600 thousand tons plus a fixed ballast which was added in order to prevent platform shifting. Reservoirs which may accept 1.3 million crude oil barrels are installed inside the base structure. The design ensures protection from platform damages due to the impact of icebergs [15]

Platformy wieżowe z odciągami. Platforma z odciągami składa się z pionowej wieży zbudowanej w postaci kratownicy przestrzennej, ustawionej na odpowiedniej podstawie, utrzymywanej w pionie za pomocą od 16 do 24 odciągów zamocowanych do kotwic zainstalowanych na dnie morza (rys. 7). Niektóre rozwiązania platform z odciągami zawierają obciążniki na odciągach blisko kotwic. Ze względu na to, że siły poziome przenoszone są przez odciągi, w konstrukcjach wymagana jest znacznie mniejsza ilość stali niż w stalowych platformach wieżowych [1]. Platforma wieżowa $z$ odciągami może być stosowana do głębokości wody $600 \mathrm{~m}$ i większej. Najmniejsza głębokość, na jakiej można stosować te platformy, wynosi ok. $200 \mathrm{~m}$. Pierwszą platformę z odciągami o nazwie „Lena” ustawiono w 1983 r. na głębokości 305 m w Zatoce Meksykańskiej. Wieżę platformy wykonano w jednym odcinku o długości $321 \mathrm{~m}$ i ciężarze 270 MN [1].

Platformy pionowo kotwiczone (ang. TLP - Tension Leg Platforms). Platformy te składają się z pływającego kadłuba o kształcie i rozwiązaniu zbliżonym do platformy półzanurzonej (rys. 8). Kadłub jest zakotwiczony w taki sposób, aby liny lub cięgna kotwiczne biegły pionowo lub prawie pionowo, a nie ukośnie, tak jak w konwencjonalnym układzie kotwicznym platform półzanurzanych. Alternatywne koncepcje lin kotwiących zakładają stosowanie kabli lub rur, tj. wykorzystanie do kotwiczenia specjalnie dostosowanych kolumn

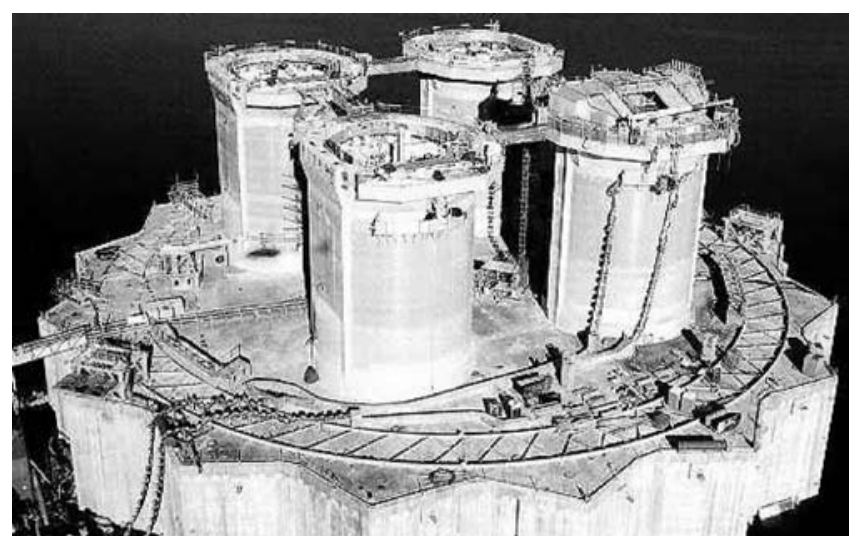

Rys. 6. Podstawa platformy Hibernia wykonana z wysoko wytrzymałego betonu wzmocnionego stalowym zbrojeniem, wstępnie obciążonym [7]

Fig. 6. Hibernia-type Platform base made of steel reinforced prestressed concrete featuring high resistance [7]

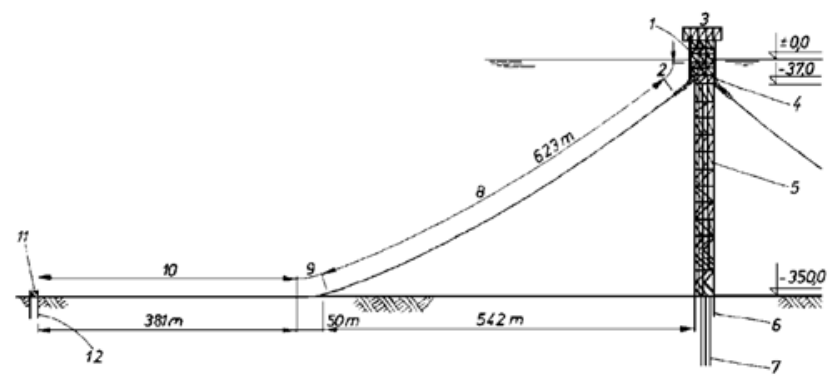

Rys. 7. Schemat platformy $z$ odciągami i $z$ wieżą posadowioną na palach; 1 - łańcuch napinający, 2 - łańcuch, 3 - pokład, 4 - przytrzymywacz łańcucha, 5 - wieża, 6 - pale obwodowe, 7 - pale nieiniektowane, 8 - odciąg, 9 - układ obciążników, 10 - odciąg wleczony, 11 - konstrukcja kotwiąca, 12 - pale kotwiące [1]

Fig. 7. Diagram of platform with backstays and tower founded on piles; 1 - tension chain, 2 - chain, 3 - deck, 4 -chain stay, 5 - tower, 6 - ring piles, 7 - non-PIFs, 8 - backstay, 9 - system of sinker bars, 10 - towed backstay, 11 - anchor structure, 12 - anchor piles [1]

prowadnikowych. Liny lub cięgna kotwiczne są zawsze pod działaniem znacznych sił rozciągających, wynikających z dodatkowej wyporności w dolnej części pokładu. Gdy platforma jest przemieszczana z założonego położenia pod wpływem działania wiatru, falowania i prądów, wypadkowa składowa pozioma rozciągania liny kotwicznej wykazuje tendencje do przyciągnięcia platformy do jej pierwotnego położenia [1]. Spodziewane ruchy tego typu konstrukcji są bardzo duże w porównaniu z platformami stałymi i z tego względu możliwe do stosowania tylko w głębszych wodach, gdzie ruch ten nie wywoła dodatkowych obciążeń na kolumny odwiertów eksploatacyjnych [1].

Platformy półzanurzone (ang. semi-submersible platforms). Platformy półzanurzone (rys. 9) swą pływalność i stateczność zawdzięczają „dolnemu kadłubowi”, który jest połączony kolumnami z platformą właściwą [4]. Mogą być one przemieszczane z miejsca na miejsce. Generalnie platformy te podczas pracy są zakotwiczane. Mogą być również utrzymywane w odpowiedniej pozycji przez system dynamicznego pozycjonowania. Głębokość wody, na której mogą pracować, wynosi od $180 \mathrm{~m}$ do $1800 \mathrm{~m}$ [3].

Platformy typu SPAR. Platformy są zakotwiczone do dna morskiego tak jak platformy TLP, ale mają bardziej konwencjonalne liny kotwiące (rys. 10). Około $90 \%$ konstrukcji tych platform znajduje się pod powierzchnią wody [3, 8]. Zostały 


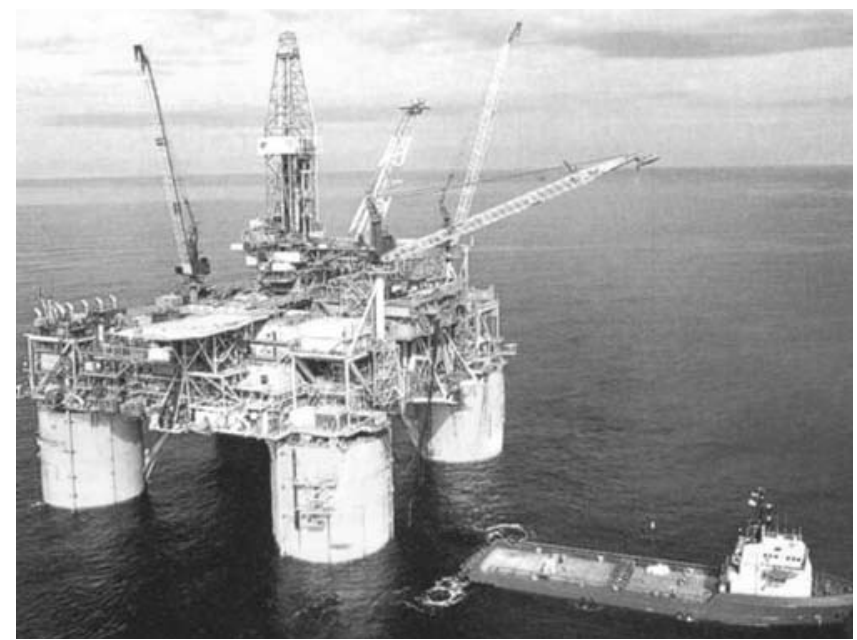

Rys. 8. Platforma pionowo kotwiczona URSA unosi się na głębokości wody ponad $1100 \mathrm{~m}$ w Zatoce Meksykańskiej. Jest to jedna z największych platform typu TLP na świecie. Produkuje 150 tys. baryłek ropy naftowej i ponad $11 \mathrm{mln} \mathrm{m}^{3}$ gazu dziennie. Może na niej mieszkać jednocześnie 110 osób [7]

Fig. 8. URSA-type Platform with vertical anchoring system. It floats on more than 1,100 $\mathrm{m}$ deep waters of the Gulf of Mexico. One of the biggest TLP-type platforms in the world. Its output amounts to 150 thousand crude oil barrels and more than 11 million $\mathrm{m}^{3}$ gas a day. It may house 110 persons at the same time [7]

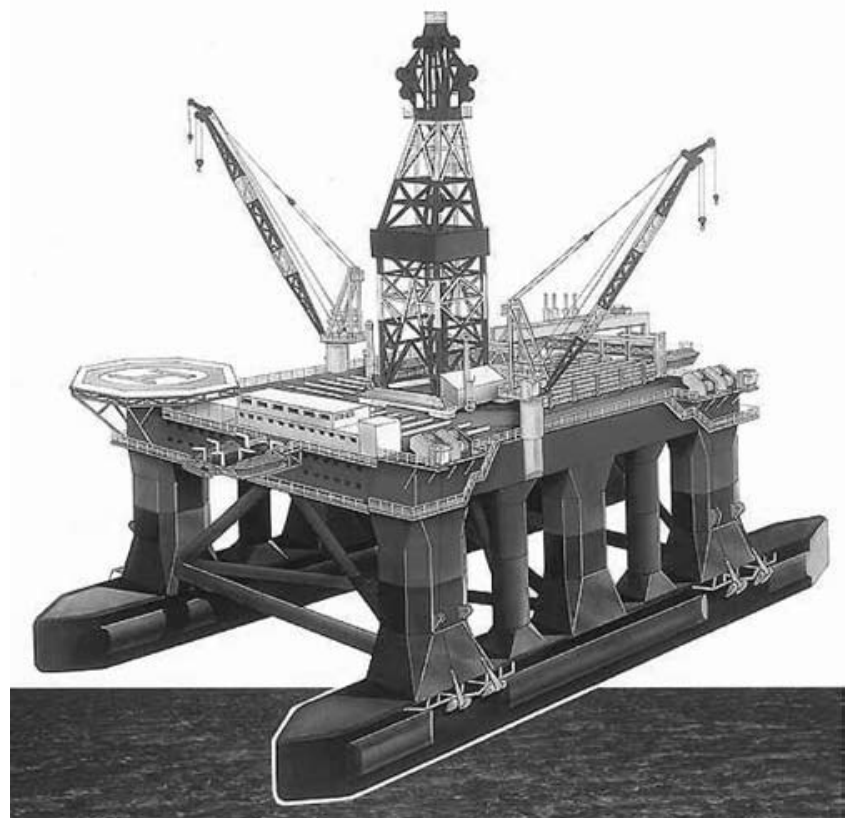

Rys. 9. Platforma półzanurzona Marine 700 [7]

Fig. 9. Semi-submersible Marine 700 Platform [7]

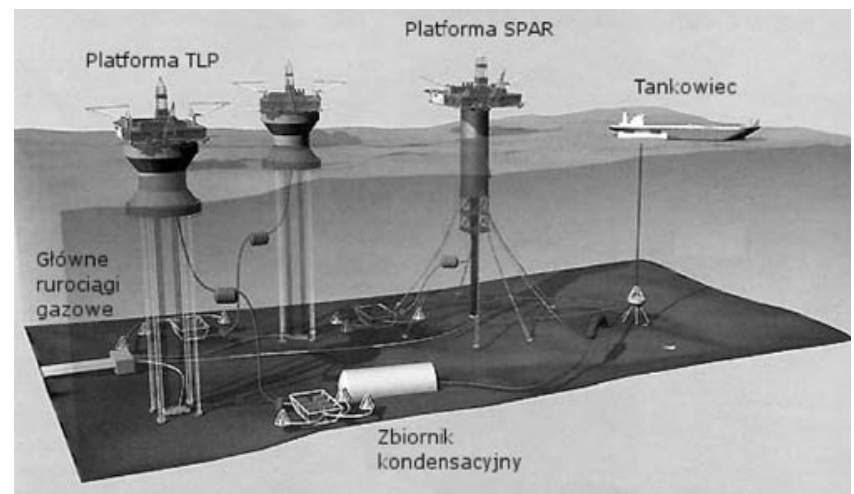

Rys. 10. Widok części nadwodnych i podwodnych platform TLP i SPAR wraz z instalacją [7]

Fig. 10. View of topside and submarine components of TLP and SPAR platforms including their systems [7]

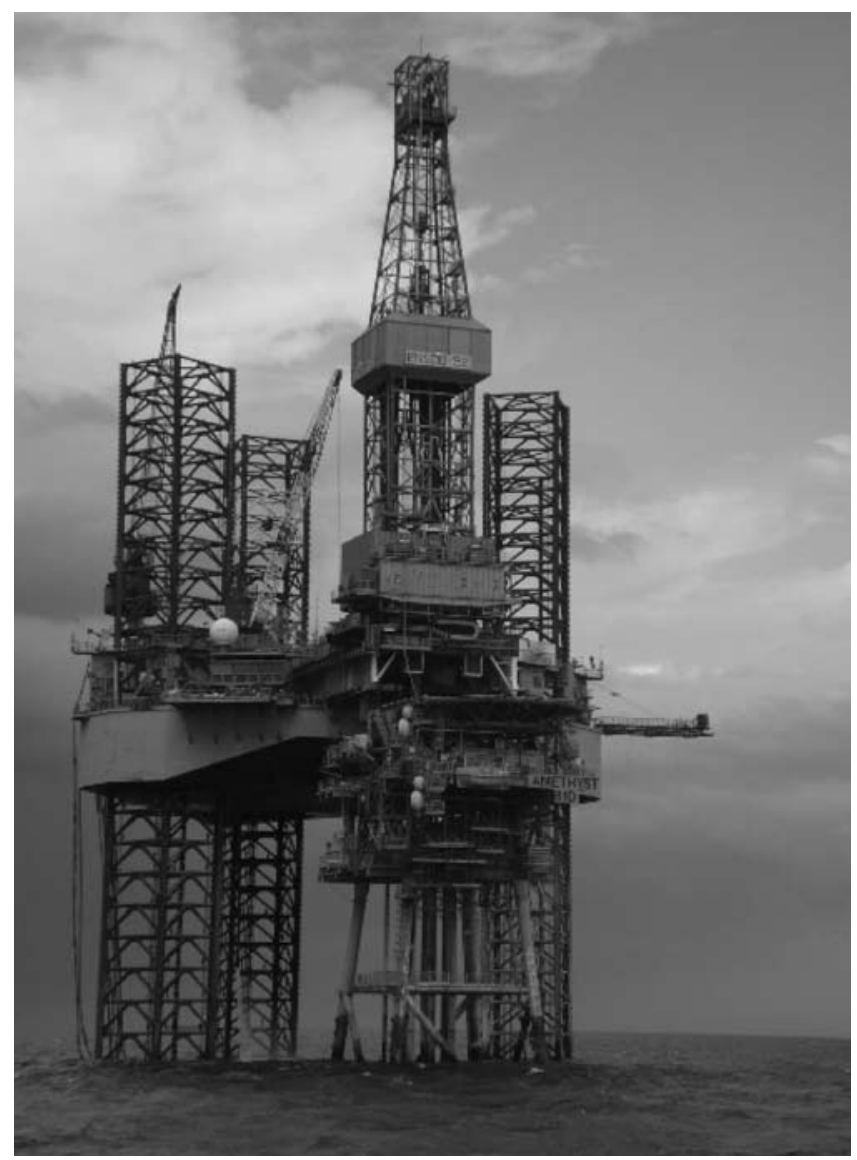

Rys. 11. Platforma Ensco 92 typu jack-up ustawiona nad stałą platformą wieżową w celu dokonania odwiertu pod stałą platformą (Morze Północne) [5]

Fig. 11. Ensco 92 jack-up type platform installed above the fixed tower platform in order to perform bore-holes under the fixed platform (The North Sea) [5]

zaprojektowane w trzech konfiguracjach: konwencjonalnej, kratownicowej i komórkowej. Ich budowa może być tańsza od platform TLP, mają też większą stabilność niż TLP ze względu na nisko umieszczoną przeciwwagę, dlatego utrzymanie platformy w pionie w niewielkim stopniu zależy od zakotwiczenia [3].

Platformy samopodnośne (ang. jack-up platforms). Mogą one podnieść się ponad poziom morza za pomocą opuszczanych „nóg”. Konstrukcja platformy zapewnia jej pływalność, dzięki temu, po podniesieniu „nóg”, można ją łatwo przestawić w inne miejsce. Wysoka mobilność i stabilność platform samopodnośnych sprawia, że są one bardzo często stosowane do wiercenia studni nad platformami stałymi (rys. 11). Mają wieżę wiertniczą umieszczoną na wysuwanym hydraulicznie ramieniu. Platforma samopodnośna ustawiana jest obok platformy stałej i opuszcza nogi na dno akwenu. Następnie wysuwa ramię $z$ wieżą wiertniczą nad platformę stałą.

\section{Statki wiertnicze}

Statek wiertniczy jest to przystosowany statek morski, wyposażony w sprzęt, który umożliwia wiercenie w morskim dnie (rys. 12). Statki te mogą być utrzymywane w odpowiedniej pozycji za pomocą systemu kotwic lub przez system dynamicznego pozycjonowania [8].

Statki te są zaprojektowane tak, aby umożliwić wiercenia na głębokich wodach. Typowy statek wiertniczy ma (oprócz oprzyrządowania wiertniczego) takie samo wyposażenie, jakie normalnie można znaleźć na morskim statku. Platforma i wieża wiertnicza są umiejscowione na środku pokładu. Pod wieżą wiertniczą znajduje się otwór przechodzący przez 


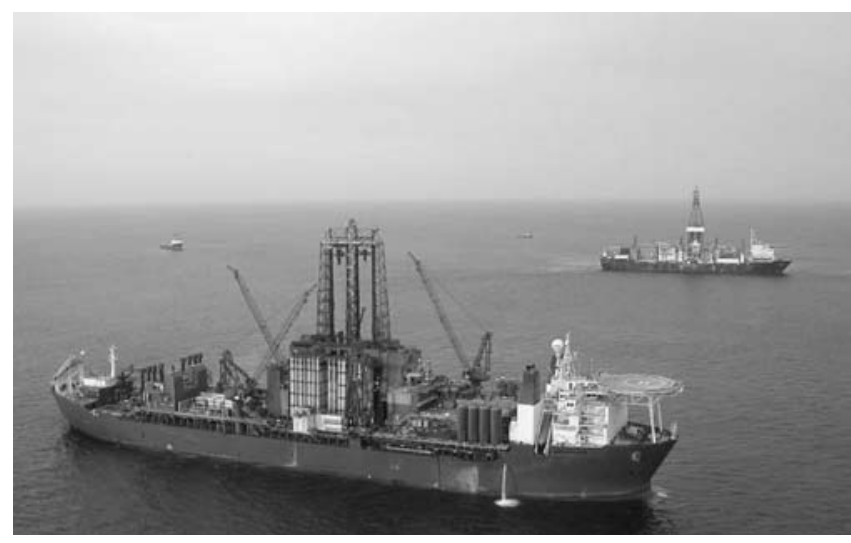

Rys. 12. Statek wiertniczy Smedvig West Navigator [5] Fig. 12. Smedvig West Navigator drilling vessel [5]

cały kadłub, który umożliwia opuszczenie kolumny przewodu wiertniczego do wody [8]. Statki wiertnicze są generalnie przeznaczone do wiercenia na głębokich wodach w odległych lokalizacjach, na obszarach o umiarkowanej pogodzie, za względu na ich mobilność i dużą zdolność załadowczą. Ze względu na konwencjonalny kształt kadłuba statku jest on bardzo podatny na ruchy morza, bardziej niż platformy półzanurzone. $Z$ tego powodu statki wiertnicze znajdują większe zastosowanie (ale nie zawsze) na spokojniejszych wodach, podczas gdy platformy półzanurzone mogą pracować w najbardziej nieprzyjaznym otoczeniu [8].

\section{Pływający Punkt Produkcji, Przechowywania i Załadunku (ang. FPSO - Floating Production, Storage and Offloading)}

FPSO jest zbliżony do tankowca, który oprócz zbiorników do magazynowania ropy i gazu ma oprzyrządowanie do wstępnej obróbki minerałów wydobywanych spod dna morskiego (rys. 13). Odbiera surową (nieprzerobioną) ropę naftową z głębinowych studni i magazynuje ją w zbiornikach do czasu, kiedy surowa ropa może być wypompowana do wahadłowego tankowca lub na barkę morską, które przetransportują ładunek na brzeg [14]. FPSO są używane do rozwijania morskich pól naftowych na całej Ziemi od późnych lat 70. XX w. Przeważnie są używane na Morzu Północnym, w Brazylii, południowo-wschodniej Azji, na południowych morzach Chin, na Morzu Śródziemnomorskim, w Australii i przy zachodnich wybrzeżach Afryki. W 2004 r. na świecie było ok. 70 FPSO (eksploatowanych i budowanych razem) [14].

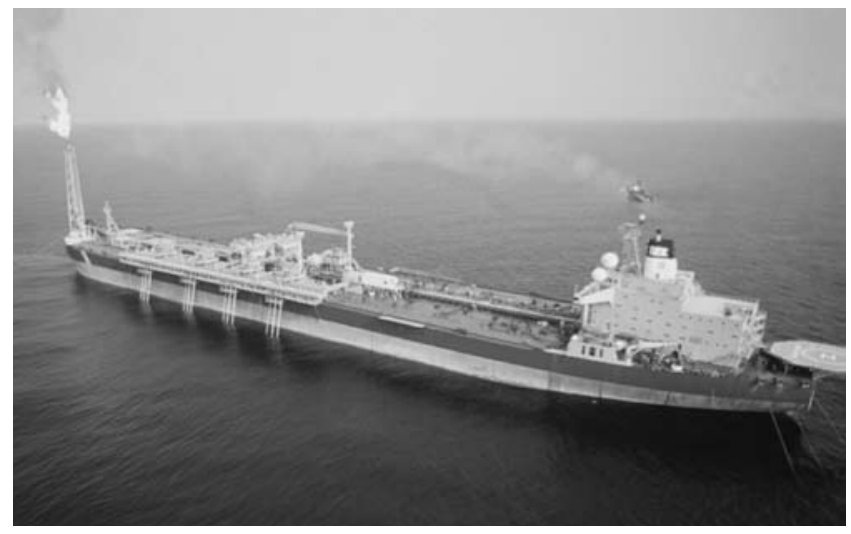

Rys. 13. FPSO Sendje Berge na polu Ceiba [9] Fig. 13. FPSO Sendje Berge on Ceiba field [9]

\section{Naprawy i remonty konstrukcji offshore}

Remonty konstrukcji pełnomorskich stwarzają wiele problemów:

- konstrukcje stałe wymagają remontu na pełnym morzu; konstrukcje mobilne, takie jak: platformy półzanurzone i samopodnośne, mają ograniczone możliwości transportowe (specjalistyczny zespół holujący, stan morza), co powoduje duże rozbieżności między planowanym i rzeczywistym harmonogramem remontu;

- wysoki koszt wyłączenia platformy z eksploatacji wpływa (korzystnie) na maksymalne skrócenie czasu remontu; koszt dzienny wyłączenia platformy samopodnośnej Noble Piet to 55 tys. dolarów, a koszt dzienny platformy półzanurzonej Eirik Raude to aż 250 tys. dolarów;

- klimat w miejscu przeprowadzania remontu takim jak Morze Północne, poważnie ogranicza prace na wolnym powietrzu, co wymusza dużą pracochłonność przy przygotowaniu zabezpieczeń dla prac montażowo-spawalniczych;

- procedury zapewnienia bezpieczeństwa wymagają każdorazowo zdobycia pozwoleń na prowadzenie prac spawalniczych [4].

Oprócz typowego zużycia eksploatacyjnego, do którego w bardzo dużym stopniu zalicza się zużycie rurociągów, które zajmują większość powierzchni platformy i przez które bezustannie tłoczone są wydobywane minerały, konstrukcje te mogą wymagać naprawy po uszkodzeniach w wyniku działania falowania, czy też w wyniku uderzenia statku, pożaru lub awarii powstałych już podczas montażu [1].

Analiza napraw wskazuje, że są one możliwe wówczas, gdy konstrukcja jest stateczna. W innym przypadku istnieje zbyt duże zagrożenie dla ludzi. Istotnym problemem jest prowadzenie bieżących badań umożliwiających wykrycie uszkodzeń w takim czasie, aby naprawa w ogóle była możliwa [1].

Generalnie prace remontowe za pomocą metod spawalniczych można podzielić na dwa rodzaje: wycinanie zużytych lub uszkodzonych elementów i wstawianie nowych oraz remont metodą napawania zużytych elementów. W związku z tym, że w przypadku konstrukcji offshore remont musi być przeprowadzony niezwykle szybko, a wyremontowane elementy muszą spełniać surowe wymogi norm, najczęstszym rodzajem remontu tych konstrukcji jest wycięcie elementu i wstawienie nowego, przygotowanego wcześniej. Operacja ta nie różni się znacząco od pierwotnego wytwarzania tych konstrukcji.

\section{Przepisy dotyczące konstrukcji offshore}

NORSOK jest inicjatywą norweskiego przemysłu offshore, którego celem jest optymalizacja kosztów i poprawa bezpieczeństwa w tym sektorze [4]. Celem wprowadzenia norm serii NORSOK jest ustalenie standardów zapewniających właściwe bezpieczeństwo i efektywne wykorzystanie nakładów w przemyśle petrochemicznym [4]. Norma NORSOK jest podzielona na 29 części, obejmujących m.in. takie dziedziny, jak: administracja, operacje wiertnicze i wydobywcze, elektrotechnika, konstrukcje, urządzenia podwodne, materiały, rurociągi, analiza ryzyka [4]. Z tego samego powodu co seria norm NORSOK powstały wymagania opracowane przez Towarzystwo Det Norske Veritas (DNV). Obejmują one wszystkie etapy powstawania konstrukcji, począwszy od projektowania, poprzez wytwarzanie, kończąc na odbiorze. 


\section{Wymagania dotyczące materiałów podstawowych i dodatkowych używanych do napraw konstrukcji stalowych typu offshore}

Towarzystwo DNV dzieli materiały na konstrukcje pełnomorskie (wg OS-B101) na trzy grupy wytrzymałościowe: NS (ang. normal strength) - stale zwykłej jakości; HS (ang. high strength) - stale o wysokiej wytrzymałości; EHS (ang. extra high strength) - stale o bardzo wysokiej wytrzymałości (tabl . II).

Dodatkowo każda z tych grup może charakteryzować się zwykłą spawalnością lub podwyższoną oznaczaną następująco [10]:

- NV xy dla stali o normalnej spawalności,

- NV xWy dla stali o podwyższonej spawalności.

Tablica II. Gatunki stali wg DNV OS-B101 [10]

Table II. Steel grades according to DNV OS-B101 [10]

\begin{tabular}{|c|c|c|c|c|c|}
\hline \multirow{3}{*}{ 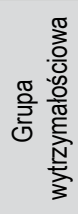 } & \multicolumn{3}{|c|}{ Próba udarności } & \multicolumn{2}{|c|}{ Właściwości mechaniczne } \\
\hline & \multicolumn{2}{|c|}{ Symbol x } & \multirow{2}{*}{$\begin{array}{c}\text { temp. } \\
\text { badania } \\
{ }^{\circ} \mathrm{C}\end{array}$} & \multirow{2}{*}{$\begin{array}{c}\text { symbol } \\
y\end{array}$} & \multirow{2}{*}{$\begin{array}{c}\text { minimalna } \\
\text { granica } \\
\text { plastycznościl1, } \\
\mathrm{N} / \mathrm{mm}^{2}\end{array}$} \\
\hline & $\begin{array}{c}\text { zwykła } \\
\text { spawalność }\end{array}$ & $\begin{array}{c}\text { podwyższona } \\
\text { spawalność }\end{array}$ & & & \\
\hline NS & $\begin{array}{l}A \\
B^{2)} \\
D \\
E\end{array}$ & $\begin{array}{l}- \\
\text { BW } \\
\text { DW } \\
\text { EW }\end{array}$ & $\begin{array}{r}- \\
0 \\
-20 \\
-40\end{array}$ & $\begin{array}{l}\text { pomi- } \\
\text { nięto }\end{array}$ & 235 \\
\hline HS & $\begin{array}{l}A \\
D \\
E \\
F\end{array}$ & $\begin{array}{c}\text { AW } \\
\text { DW } \\
\text { EW } \\
-\end{array}$ & $\begin{array}{r}0 \\
-20 \\
-40 \\
-60\end{array}$ & $\begin{array}{l}27 \\
32 \\
36 \\
40\end{array}$ & $\begin{array}{l}265 \\
315 \\
355 \\
390\end{array}$ \\
\hline EHS & $\begin{array}{l}A \\
D \\
E \\
F\end{array}$ & $\begin{array}{c}- \\
\text { DW } \\
\text { EW } \\
-\end{array}$ & $\begin{array}{r}0 \\
-20 \\
-40 \\
-60\end{array}$ & $\begin{array}{l}42 \\
46 \\
50 \\
55 \\
62 \\
69\end{array}$ & $\begin{array}{l}420 \\
460 \\
500 \\
550 \\
620 \\
690\end{array}$ \\
\hline \multicolumn{6}{|c|}{$\begin{array}{l}\text { Uwagi: } \\
\text { 1) Dla stali o podwyższonej spawalności wymagania dla minimalnej granicy } \\
\text { plastyczności zostały zredukowane dla rosnącej grubości materiału. } \\
\text { 2) Próba udarności jest wymagana dla grubości powyżej } 25 \mathrm{~mm} \text {, ale dla } \\
\text { grubości } 25 \mathrm{~mm} \text { lub mniejszej jest przedmiotem porozumienia. }\end{array}$} \\
\hline
\end{tabular}

\section{Materiały dodatkowe do spawania wg DNV}

Materiały dodatkowe do spawania konstrukcji stalowych typu offshore muszą być zatwierdzone przez Towarzystwo Klasyfikacyjne. Zatwierdza się je na podstawie wymagań „Przepisów Klasyfikacji Statków” DNV (Rules for Classification of Ships, punkt 2, rozdział 3, sekcja 3) [13]. Wszystkie znaki towarowe, pod którymi materiały są badane i zatwierdzane, powinny być zarejestrowane przez Towarzystwo. W celu uniknięcia sytuacji podwajania badań dla tego samego materiału dodatkowego, wytwórca powinien wydawać zaświadczenie, że dany materiał dodatkowy dostarczany pod inną nazwą lub oznaczeniem jest identyczny $z$ materiałem dodatkowym, który uzyskał zatwierdzenie Towarzystwa Klasyfikacyjnego [13].

\section{Stale na konstrukcje stalowe offshore według NORSOK}

Materiały na konstrukcje stalowe pełnomorskie offshore zestawiono w normie NORSOK M-120. Oznaczenie tych materiałów oraz ich właściwości odpowiadają normom europejskim (EN), co obrazuje tabl. III.

Tablica III. Wybrane stale konstrukcyjne według NORSOK $\mathrm{M}-120$ [11]

Table III. Selected machine steel grades according to NORSOK M-120 [11]

\begin{tabular}{|c|c|c|c|c|}
\hline 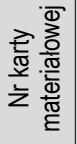 & Norma & $\begin{array}{c}\text { Gatunek } \\
\text { stali }\end{array}$ & Rodzaj produktu & 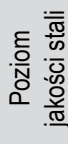 \\
\hline Y01 & $\begin{array}{l}\text { EN } 10025 \\
\text { EN } 10210 \\
\text { EN } 10219\end{array}$ & $\begin{array}{l}\text { S235JRG2 } \\
\text { S235JRH } \\
\text { S235JRH }\end{array}$ & $\begin{array}{l}\text { blachy i kształtowniki } \\
\text { rury walcowane na gorąco } \\
\text { rury walcowane na zimno }\end{array}$ & IV \\
\hline Y07 & EN 10210 & S355/NH & rury walcowane na gorąco & III \\
\hline Y08 & EN 10219 & S355MLH & rury walcowane na zimno & III \\
\hline Y15 & EN 10113 & S420NL/ML & blachy i kształtowniki & III \\
\hline Y16 & EN 10219 & S420MLH & rury walcowane na zimno & III \\
\hline Y20 & EN 10225 & $\begin{array}{l}\text { S355G10+N/ } \\
\text { G10+M }\end{array}$ & blachy & I \\
\hline Y21 & EN 10225 & $\begin{array}{l}\text { S355G12+N/ } \\
\text { G12+M }\end{array}$ & walcowane kształtowniki & 1 \\
\hline Y27 & EN 10225 & $\begin{array}{l}\text { S355G14+Q/ } \\
\text { G14+N }\end{array}$ & rury bezszwowe & II \\
\hline Y28 & EN 10225 & $\mathrm{~S} 355 \mathrm{G} 13+\mathrm{N}$ & rury spawane & II \\
\hline
\end{tabular}

\section{Materiały dodatkowe do spawania wg NORSOK}

Wytwórca musi zapewnić, aby materiały dodatkowe użyte do spawania, gdzie jest wymagana jakość stali I, II i III (poziomy jakości stali wg tabl. III), spełniały wymagania mechaniczne wymagane dla WPQ (Welding Procedure Qualification) zarówno po spawaniu, jak i po obróbce cieplnej [12]. $Z$ wyjątkiem drutów pełnych, materiały dodatkowe powinny być sklasyfikowane przez dostawcę jako materiały o bardzo niskiej zawartości wodoru $\mathrm{H}_{\mathrm{DM}} \leq 5 \mathrm{ml} / 100 \mathrm{~g}$ w spawanym metalu. Dla drutów samoosłonowych akceptowalny jest poziom $\mathrm{H}_{\mathrm{DM}} \leq 8 \mathrm{ml} / 100 \mathrm{~g}$, jeżeli stosuje się podgrzewanie wstępne i zapobiega szybkiemu ochłodzeniu materiału po spawaniu (w celu wyeliminowania pęknięć wodorowych). Testy na zawartość wodoru powinny być zgodne z normą ISO 3690 [12].

Dla wszystkich stali z określoną minimalną granicą plastyczności ponad $500 \mathrm{MPa}$ powinny być podjęte specjalne środki ostrożności w celu zweryfikowania, czy wybrany materiał dodatkowy spełnia wymagania co do obecności wodoru. Prefabrykacja powinna być tak prowadzona, aby była możliwość odkształcenia się materiału podczas spawania lub montażu [12]. Materiały dodatkowe do spawania stali o poziomie jakości III (minimalna granica plastyczności $\geq 355 \mathrm{MPa}$ ) i IV oraz połączenia stali nierdzewnej i stali konstrukcyjnej powinny być dobrane z uwzględnieniem właściwości materiału rodzimego, jego grubości i spawalności, w celu zapewnienia wymaganej wytrzymałości, ciągliwości i jednorodności połączenia spawanego [12]. Wszystkie materiały dodatkowe do spawania powinny być oznaczone [12]. 
Wymagania dotyczące instrukcji technologicznej spawania (WPS) wg DNV OS-C401

W instrukcji technologicznej spawania powinny być określone:

- materiał: norma, gatunek, odmiana;

- grubość nominalna lub średnice;

- rodzaj procesu spawania;

- połączenie lub rowek spawalniczy wraz z tolerancjami;

- pozycja spawania (pozycje) i kierunek spawania;

- materiały dodatkowe do spawania: nazwa handlowa, średnica elektrod bądź drutu, gaz osłonowy, topnik i jego klasyfikacja;

- kolejność spawania: liczba i kolejność układania warstw;

- parametry prądowe: napięcie, natężenie, biegunowość;

- prędkość spawania i ilość wprowadzonego ciepła;

- podgrzewanie wstępne i temperatura międzyściegowa;

- obróbka cieplna po spawaniu;

- oczyszczenie spoiny po spawaniu i inne uwagi [13].

\section{Ważność instrukcji technologicznej spawania wg DNV OS-C401}

Ważność instrukcji technologicznej spawania jest ograniczona tylko dla zakładu produkcyjnego, dla którego została zatwierdzona. Zakłady pracujące jako podwykonawca zakładu, który uzyskał zatwierdzenie WPS-u, mogą być traktowane jako jeden zakład pod warunkiem, że mają tę samą kadre zarządzającą technologią oraz pracują według tych samych procedur. Instrukcja spawania pozostaje ważna pod warunkiem, że zasadnicze parametry procesu są utrzymywane podczas produkcji na takim samym poziomie, jakiego wymaga instrukcja (szczegółowy opis parametrów, które wpływają na konieczność opracowania nowego WPS-u, znajduje się w OS-C401) [13]. Instrukcja technologiczna spawania powinna być sporządzona w oparciu o procedurę uznania technologii spawania zgodnie z normą EN ISO 15614-1 i wymaganiami DNV OS-C401.

\section{Kwalifikacja instrukcji technologicznej wg NORSOK}

Instrukcja technologiczna przeznaczona do wykonywania konstrukcji pełnomorskich wymaga stosowania stali o klasie I i II dla wszystkich poziomów wytrzymałości oraz klasy III dla stali o minimalnej granicy plastyczności $\geq 355 \mathrm{MPa}$ (kwalifikowana zgodnie z normą EN ISO 15609-1). Kwalifikacja jest zasadniczo przyznana wytwórcy, który wykonywał złącza próbne do uznania technologii spawania oraz dla wytwórców, którzy podlegają nadzorowi technicznemu i technologicznemu wytwórcy, dla którego została zaakceptowana instrukcja technologiczna. Kwalifikacja może również być używana przez podwykonawcę pod warunkiem, że wdrożona i udokumentowana jest norma EN ISO 3834 (systemy jakości w spawalnictwie).

\section{Odbiór konstrukcji}

Towarzystwo Kwalifikacyjne DNV definiuje trzy kategorie inspekcji: I, II i III, przy czym najwyższa jest kategoria I (największy procent badań nieniszczących). Dodatkowo należy również określić klasę konstrukcji zdefiniowanych klas: specjalna, podstawowa oraz drugorzędna, przy czym najwyższy poziom wymagań jest dla klasy konstrukcji specjalnej. Norma NORSOK definiuje pięć kategorii inspekcji: A, B, C, D i E. Najwyższa jest kategoria A (najwyższy procent badań nieniszczących). Różnią się one między sobą procentem badań nieniszczących różnych metod. W przypadku kategorii inspekcji A i B oraz C, D i E kryteria akceptacji są jednakowe.

\section{Naprawy wg wymagań DNV}

Naprawy powinny być wykonywane zgodnie z kwalifikowaną procedurą naprawy, która jest tematem do uzgodnienia. Wytyczne dotyczące naprawy znajdują się w IACS „Shipbuilding and repair Quality Standard" (International Association of Classification Societies - Międzynarodowe Stowarzyszenie Klasyfikacyjne „Budowa i naprawa statków, normy”), część $A$, sekcja 9 i część B [13]. Elementy odkształcone na skutek spawania mogą być prostowane środkami mechanicznymi lub przez kontrolowane nagrzewanie miejscowe. Nagrzewanie albo prostowanie mechaniczne powinno być prowadzone zgodnie z opracowanymi i zatwierdzonymi procedurami [13]. Niezgodności w spoinach mogą być poprawiane przez szlifowanie, skrawanie lub spawanie. Spoiny o niewystarczającej wytrzymałości, ciągliwości lub z karbem powinny być usunięte w pierwszej kolejności i naprawione. Właściwości mechaniczne naprawionych spoin powinny być co najmniej takie jak materiału rodzimego [13]. To samo miejsce spawania można naprawiać tylko dwa razy, kolejne naprawy muszą być rozpatrywane indywidualnie [13].

Każdorazowo po usunięciu niezgodności spawalniczej, strefa wyżłobiona i graniowa powinny być kontrolowane metodą magnetyczno-proszkową lub inną odpowiednią do sytuacji - w celu potwierdzenia kompletnego usunięcia wady [13]. Naprawa powinna być wykonywana przy użyciu materiałów dodatkowych o wymaganym poziomie wodoru. Temperatura podgrzewania wstępnego i robocza, podczas wykonywania płytkich i lokalnych napraw w specjalnych i głównych elementach konstrukcyjnych, powinna wzrosnąć o $50^{\circ} \mathrm{C}$ powyżej poziomu określonego przy wytwarzaniu i wynosić co najmniej $100^{\circ} \mathrm{C}$, chyba że uzgodniono inaczej. Temperatura powinna być utrzymywana, dopóki naprawa nie zostanie zakończona, długość spoiny naprawianej nie może być krótsza niż 50 mm [13].

Naprawa powinna być wykonana przez usunięcie wadliwej części spoiny bez istotnego usunięcia materiału rodzimego. W przypadku wad płaskich należy usunąć $50 \mathrm{~mm}$ więcej z każdej strony, niż wynosi długość wady wykazana podczas badań nieniszczących. Dłuższe wady mogą wymagać naprawy w kilku krokach, aby uniknąć przegrzania czy pękania. Każdy krok naprawy powinien być kontrolowany, aby nie dopuścić do odkształceń plastycznych materiału rodzimego podczas usuwania wady [13]. Naprawa wady w złączu po obróbce cieplnej wymaga uzyskania zgody na ponowną obróbkę cieplną [13]. Mało znaczące nieciągłości mogą zostać usunięte przez szlifowanie bądź skrawanie, przez wykonanie gładkiego przejścia do materiału rodzimego. Grubość materiału nie powinna zostać zmniejszona do mniej niż 93\% nominalnej grubości, ale nie więcej niż $3 \mathrm{~mm}$. Obszar takich na- 
praw powinien być wcześniej zaakceptowany [13]. Wszystkie naprawy powinny być ponownie zbadane tymi samymi metodami badań nieniszczących, na tym samym bądź rozszerzonym obszarze [13].

\section{Naprawy wg wymagań NORSOK}

\begin{abstract}
Naprawianie spoin z niezgodnościami
Wszystkie naprawy powinny być wykonywane zgodnie z ustalonymi procedurami. Spoiny zawierające pęknięcia nie powinny być naprawiane, dopóki przyczyna pękania nie zostanie usunięta. Jeżeli jest taka potrzeba, wadliwą część połączenia można wyciąć w celu wykonania badań. Kratery w spoinach mogą być naprawione poprzez szlifowanie i późniejsze badanie nieniszczące a następnie zaspawanie według zaakceptowanych procedur [12]. Inne wady powinny być naprawione przez szlifowanie, a następnie ponowne spawanie [12]. Jeżeli wada spoiny zostanie usunięta tylko przez szlifowanie, zaleca się łagodne przejście spoiny w materiał rodzimy. Usuwanie wad powinno być nadzorowane przez inspektorów badań wizualnych korzystających z odpowiednich metod badań nieniszczących. Jeżeli jest to możliwe, pozostała część spoiny powinna być zmierzona. Naprawa jest konieczna, jeżeli pozostała po usunięciu niezgodności część spoiny ma mniejszą grubość niż wymagana [12].
\end{abstract}

\section{Naprawa metodami spawalniczymi}

Przed rozpoczęciem naprawy spoiny niezgodność powinna być całkowicie usunięta. Wycięta strefa powinna mieć gładkie przejście do powierzchni materiału rodzimego i umożliwiać dobry dostęp do wykonania badań nieniszczących po wycięciu i późniejszym spawaniu. Wyżłobienie i kompletne usunięcie niezgodności powinno zostać potwierdzone badaniami magnetyczno-proszkowymi lub penetracyjnymi. Obróbka cieplna po spawaniu powinna być wykonana po naprawie, jeżeli jest wymagana dla pierwotnej spoiny [12]. Wycinany rowek musi mieć minimum $50 \mathrm{~mm}$ długości, nawet jeśli niezgodność jest mniejsza. Niezgodności, które są od siebie oddalone o mniej niż $100 \mathrm{~mm}$, powinny być naprawiane jak jedna ciągła niezgodność [12]. Po naprawie zakończona spoina (naprawiony obszar i minimum po 100 mm z każdej strony) powinna być poddana przynajmniej takim samym badaniom nieniszczącym, jakie były wymagane dla spoiny pierwotnej [12].

Naprawa spoiny może być wykonana tylko dwukrotnie w tym samym miejscu. Ponowne spawanie powinno być wykonane zgodnie z procedurami i instrukcjami technologicznymi spawania wykorzystanymi do pierwotnego wykonania złącza (po całkowitym usunięciu pierwotnej spoiny i srefy wpływu ciepła) [12]. Instrukcja technologiczna naprawy i instrukcja technologiczna ponownej naprawy mogą być opracowane na podstawie tej samej instrukcji technologicznej, która została użyta do pierwotnej spoiny, lub jako oddzielna kwalifikowana procedura. Dla napraw, które są wykonywane przy użyciu innego procesu, lub/i przy użyciu innych materiałów dodatkowych, powinna zostać opracowana nowa instrukcja technologiczna spawania (WPS) i być kwalifikowana zgodnie $z$ aktualnymi normami, jeśli wymaga tego procedura [12]. Niewłaściwie dopasowane elementy konstrukcji powinny być odcięte i jeszcze raz pospawane według odpowiedniej kwalifikowanej instrukcji technologicznej spawania. Części odkształcone w wyniku spawania, niemieszczące się w tolerancjach, powinny zostać poprawione zgodnie z wymaganiami (wg szczegółowej instrukcji pracy, temp. prostowania powinna być zgodna z zalecaną przez producenta materiału, ale nie wyższa niż $600^{\circ} \mathrm{C}$ ) [12].

\section{Wnioski}

Konstrukcje offshore stanowią bardzo liczną grupę rozwiązań, które znacznie się od siebie różnią. Każda z nich ma inne przeznaczenie i różne środowiska pracy, dlatego każda z nich wymaga odpowiedniego podejścia. Konstrukcje te muszą być niezawodne podczas ich eksploatacji, która może wynosić nawet ok. 20 do 30 lat (najczęściej do wyczerpania się złoża). Awaria platformy najczęściej kończy się katastrofą ekologiczną i śmiercią całej załogi, której liczbebność często przekracza 100 osób na jednej jednostce. Dlatego też większość awarii, które się wydarzyły, ma wpływ na zaostrzenie przepisów w celu wyeliminowania takich katastrof w przyszłości.

Obecnie na całym świecie rośnie popyt na konstrukcje offshore. Powstają stocznie, które specjalizują się wyłącznie w budowaniu takich konstrukcji; przykładem jest Keppel Fels w Singapurze, która buduje najwięcej platform wiertniczych na świecie (prawie połowę). Powstają w niej jednocześnie 23 platformy w cenie od 130 do 450 milionów dolarów. Można przypuszczać, że ze względu na ogromne zapotrzebowanie na ropę naftową popyt na te konstrukcje nie zmniejszy się.

\section{Literatura}

[1] Mazurkiewicz B.: Stałe pełnomorskie platformy stalowe. Wydawnictwo Morskie, Gdańsk 1988.

[2] Modern Marvels: Offshore Oil Drilling, lipiec 1999 (Season 5, Episode 13).

[3] http://en.wikipedia.org/wiki/Oil_platform

[4] Saperski J.: Konstrukcje Offshore. Biuletyn Instytutu Spawalnictwa, Gliwice 2007.

[5] http://www.oilrig-photos.com/sitemap.asp

[6] http://www.rigmuseum.com/history/pics5.html

[7] www.offshore-technology.com

[8] http://www.globalsecurity.org/military/systems/ship/offshore.htm

[9] http://www.equatorialoil.com/pages/Photo.htm

[10] Offshore Standard DNV-OS-B101 „Metallic Materials”, styczeń 2001.

[11] NORSOK Standard M-120 "Material data sheets for structural steel", czerwiec 2004.

[12] NORSOK Standard M-101 "Structural steel fabrication", grudzień 2000.

[13] Offshore Standard DNV-OS-C401 "Fabrication and testing of offshore structures", kwiecień 2004.

[14] http://www.globalsecurity.org/military/systems/ship/platform-fpso.htm

[15] http://www.panoramio.com/photo/1148600 